\title{
Feeding dihydroquercetin to broiler chickens
}

by Pirgozliev, V., Westbrook, C., Karagecili, M.R., Karadas, F., Rose, S.P. and Mansbridge, S.C.

Copyright, Publisher and Additional Information: This is the authors' accepted manuscript. The final published version (version of record) is available online via Taylor \& Francis

Please refer to any applicable terms of use of the publisher.

DOI: https://doi.org/10.1080/00071668.2018.1556387 


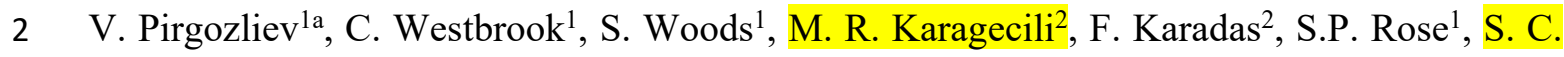

3 Mansbridge $^{1}$

$4{ }^{1}$ The National Institute of Poultry Husbandry, Harper Adams University, Shropshire, UK;

$5 \quad{ }^{2}$ Department of Animal Science, Yuzuncu Yil University, Van, Turkey

$6 \quad{ }^{a}$ Corresponding author: vpirgozliev@harper-adams.ac.uk

7 Abstract 1. A total of 80 male Ross 308 broilers were used in a study to investigate the effect 8 of dietary dihydroquercetin (DHQ) on growth performance variables, gastrointestinal tract 9 (GIT) and immune organ development, glutathione peroxidase (GPx) and haemoglobin in 10 blood, hepatic vitamin E content, dietary N-corrected metabolisable energy (AMEn), and 11 nutrient retention coefficients when fed to broiler chickens from 7 to 35 days of age.

12 2. Two treatments were used in this study: control (C) and $\mathrm{C}+0.5 \mathrm{~g} / \mathrm{kg}$ extract of Siberian 13 Larch (Larix sibirica) per kg feed, containing $85 \%$ DHQ. The diets were fed over two feeding 14 phases, a grower phase from 7 to $28 \mathrm{~d}$ age, and a finisher phase from 28 to $35 \mathrm{~d}$ age. The birds 15 were reared under breeder's recommended conditions.

16 3. In general, there were no effects of DHQ on growth performance of broiler chickens.

17 However, the results of this experiment have shown that there can be changes in redness colour 18 of the breast meat when DQH is fed. No negative effects of feeding DHQ at $0.5 \mathrm{~g} / \mathrm{kg}$ diet were 19 observed in this study.

20 4. Supplementation of poultry diets with DHQ under standard industry rearing conditions, did not improve production performance or any of the studied health variables, except an increase

22 of redness index of the breast fillets. Feeding DHQ at different doses and/or under more challenging conditions, e.g. heat stress, may however, bring positive responses.

24 Key words: broilers, dihydroquercetin (DHQ), phenols, growth performance, antioxidants 
27 The popularity of natural antioxidants to protect human and animal health and to increase the 28 shelf life of products from animal origin has increased during the past decade (Weidmann 2012;

29 Iskender et al. 2017). Flavonoids being a major sub-group representing plant polyphenols, are considered antioxidants from natural sources and as such, have been attracting attention for use in animal nutrition (Surai 2014). Dihydroquercetin (DHQ), also known as taxifolin, a flavonoid extracted from various conifers including Siberian Larch (Larix sibirica), longleaf Indian Pine (Pinus roxburghii), Himalayan Cedar (Cedrus deodara) and Chinese Yew (Taxus chinensis var. mairei), has been widely applied as an antioxidant for the surface treatment of fresh meat and fish (Semenova et al. 2008; Ivanov et al. 2009; Balev et al. 2011; Dragoev et al. 2014). Dihydroquercetin has also been incorporated in animal diets in order to enhance production performance. Fomichev et al. (2016) extensively reviewed the effect of DHQ as dietary supplement in animal production and reported enhancement in growth performance and blood variables of poultry and pigs. Research by Nikanova (2017) with piglets further supported the observations of Fomichev et al. (2016). However, Balev et al. (2015) did not find significant difference in growth performance of broilers fed DHQ from day old to 49 days when compared to the control fed birds. Torshkov (2011) reported that the breast meat from $42 \mathrm{~d}$ age broilers fed DHQ supplemented diet had higher dry matter, lower fat, lower tryptophan and the same protein content when compared to birds fed control diet only. In addition, Torshkov et al. (2014) found that feeding DHQ to broilers increases the number of red blood cells and haemoglobin concentration compared to control. However, there was no information on growth

47 performance variables in both reports. Omarov et al. (2016) reported increased protein concentration in the organs and tissues of broiler chickens when fed DHQ, however, the 
50 majority of experiments involving DHQ emphasise more on its impact on the composition of

51 various tissues (muscle, blood), while the information on performance is rarely presented. It is

52 likely that improvements seen in productive performance in some papers may be due to heat

53 stress (Fomichev et al. 2016). Rearing animals at temperatures exceeding their thermal comfort

54 zone (e.g. during summer) may be a reason for depleting levels of tissue antioxidants, thus the

55 antioxidant status of animal may be associated with the mode of action of DHQ. Since DHQ is

56 a natural flavonoid with recognised antioxidant properties, understanding its mode of action

57 may be important for enhancing health and productivity of intensely reared animals. In

58 addition, there is no information on the impact of DHQ on the development of the

59 gastrointestinal tract (GIT), immune organs, dietary available energy and nutrient retention

60 coefficients.

61 The aim of the study was to assess the impact of DHQ on growth performance variables, GIT

62 and immune system organ development, glutathione peroxidase (GPx) and haemoglobin

63 concentration in blood, dietary N-corrected metabolisable energy (AMEn), dry matter (DMR),

64 nitrogen (NR) and fat retention (FR) coefficients when fed to broiler chickens from 7 to 35

65 days of age.

66 MATERIALS AND METHODS

\section{Experimental diets}

68 Two wheat-soy-based diets were offered to the birds during the experiment. The diets were fed 69 over two feeding phases, a grower phase from 7 to $28 \mathrm{~d}$ age, and a finisher phase from 28 to

$7035 \mathrm{~d}$ age. The grower and finisher basal diets were formulated to meet breeder's 71 recommendations (Aviagen Ltd., Edinburgh, UK) (Table 1). All diets included $5 \mathrm{~g} / \mathrm{kg}$ of $\mathrm{TiO}_{2}$

72 as a marker. The basal diets were then split into two batches that had 1.) no additive (control

73 diet; C) and 2.) $0.5 \mathrm{~g} / \mathrm{kg}$ extract of Siberian Larch (Larix sibirica) (JSC NPF Flavit, IBI RAS, 
74 Pushchino city, Moscow region, Russian Federation 142290). According to the company

75 producer, this extract contains over $85 \%$ pure DHQ.

\section{Husbandry and sample collection}

77 The experiment was conducted at the National Institute of Poultry Husbandry and approved by 78 the Research Ethics Committee of Harper Adams University. A total of 85 male Ross 308 79 broilers were obtained from a commercial hatchery (Cyril Bason Ltd, Craven Arms, UK),

80 allocated to a single floor pen and offered a standard wheat-based broiler starter feed

81 formulated to meet Ross 308 nutrient requirements (Aviagen Ltd., Edinburgh, UK). At 7 d age,

8280 of the birds were allocated to 16 raised floor pens $(60 \times 60 \mathrm{~cm})$ each holding 5 birds. Each

83 of the pens had a solid floor and were equipped with an individual feeder and drinker. Feed

84 and water were fed ad libitum to birds throughout the experiment. Each diet was offered to

85 birds in 8 pens following complete randomisation. The birds were fed the experimental diets

86 from 7 to $35 \mathrm{~d}$ age, when the experiment ended. Room temperature and lighting regime met

87 commercial recommendations (Aviagen Ltd, Edinburgh, UK). The well-being of the birds was

88 checked regularly every day.

89 Birds and feed were weighed on days 7, 28 and 35 in order to determine average daily feed 90 intake (FI), average daily weight gain (WG) and to calculate the gain:feed ratio (G:F) on a pen

91 basis. For the last 3 days of the study, the solid floor of each pen was replaced with a wire 92 mesh. Excreta were collected each day for the last three days of the experiment, stored at $4{ }^{\circ} \mathrm{C}$, 93 and a representative subsample was dried at $60{ }^{\circ} \mathrm{C}$ and then milled through $0.75 \mathrm{~mm}$ screen. 94 At the end of the study, one bird per pen, selected at random, was electrically stunned and 95 blood was obtained in heparin coated tubes from the jugular vein. The organs from the GIT, 96 including proventriculus and gizzard (PG), duodenum, pancreas, jejunum, ileum, caeca and 97 liver, the heart, the spleen and the bursa of Fabricius were weighed. The colour on the surface 
of the left breast fillet was determined, and the left breast muscles were used to determine the chilling yield.

\section{Laboratory Analysis}

Dry matter (DM) in feed and excreta samples was determined by drying of samples in a forced draft oven at $105^{\circ} \mathrm{C}$ to a constant weight (AOAC 2000; method 934.01). Crude protein (6.25 $\times N$ ) in samples was determined by the combustion method (AOAC 2000; method 990.03) using a LECO FP-528 N (Leco Corp., St. Joseph, MI). Oil (as ether extract) was extracted with diethyl ether by the ether extraction method (AOAC 2000; method 945.16) using a Soxtec system (Foss Ltd., Warrington, UK). The gross energy (GE) value of feed and excreta samples was determined in a bomb calorimeter (model 6200; Parr Instrument Co., Moline, IL) with benzoic acid used as the standard. Titanium in feed and excreta was determined as explained by Short et al. (1996).

The colour score on the surface of the left breast meat within 5 minutes after slaughter was carried out using a Chroma Meter CR-400 from Konica Minolta (Sunderland, UK) to determine luminance and chromaticity scores using CIELAB scoring (where L* refers to lightness, a* refers to redness, and $b^{*}$ refers to yellowness). Areas were selected that were free of any obvious blood-related defects, such as bruises, haemorrhages, or full blood vessels (Fletcher et al. 2000). Two readings of CIE L*, a*, and b* were obtained for the breast fillet for each bird ( 2 readings/left side). The chilling yield determined on the left breast of each slaughtered chicken was also determined (Jeong et al. 2011).

The glutathione peroxidase in blood was determined using a Ransel GPx kit (Randox Laboratories Ltd., UK) that employs the method based on that of Paglia and Valentine (1967).

The concentration of hepatic vitamin E was determined using an HPLC system as previously described (Karadas et al. 2010). 
122

123

\section{Calculations}

Dietary nutrient retention coefficients were calculated using the following equation:

$$
\text { Nutrient retention coefficients }=1-\frac{\text { exnut } / \text { ext } i}{\text { dietnut } / \text { diett } i}
$$

where exnut is the concentration of the respective nutrient in the excreta, exti is the concentration of titanium dioxide in the excreta, dietnut is the concentration of the respective nutrient in the diet and dietti is the concentration of titanium in the diet.

The AMEn value of the experimental diets was determined following the method of Hill and Anderson (1958).

$$
A M E n=G E \operatorname{diet}-\frac{(G E \text { ex } X \text { dietti })}{\text { exti }}-34.39 \times N \text { retained }
$$

where AMEn $(\mathrm{MJ} / \mathrm{kg})=\mathrm{N}$-corrected apparent metabolizable energy content of the diet; GE diet and GE ex $(\mathrm{MJ} / \mathrm{kg})=\mathrm{GE}$ of the diet and excreta, respectively; dietti and exti $(\%)=$ titanium in the diet and excreta, respectively; $34.39(\mathrm{MJ} / \mathrm{kg})=$ energy value of uric acid; and $N$ retained $(\mathrm{g} / \mathrm{kg})$ is the $\mathrm{N}$ retained by the birds per kilogram of diet consumed. The retained $\mathrm{N}$ was calculated as

$$
N \text { Retained }=N \text { diet }-\frac{N \text { ex } X \text { dietti }}{\text { exti }}
$$

where $\mathrm{N}$ Diet and $\mathrm{N}$ ex $(\%)=\mathrm{N}$ contents of the diet and excreta, respectively.

The relative development of organs was determined as percent by dividing the organ weight to body weight by the respective bird and multiplying by 100 (data not included in tables).

Chilling yield of breast meat was determined from 8 carcasses per diet as follows:

$$
\% \text { Chilling yield }=\frac{\text { Post chill breast weight }}{\text { Pre chill breast weight }} X 100 \%
$$


142 where Post chill breast weight is the weight of the left breast after $24 \mathrm{~h}$ in a fridge at $4^{\circ} \mathrm{C}$ and

143 Pre chill breast weight is the weight of the left breast immediately after dissection, respectively.

\section{Statistical Analysis}

145 Statistical analysis was performed using GenStat $19^{\text {th }}$ edition statistical software (IACR

146 Rothamstead, Hertfordshire, England). A completely randomised one-way analysis of variance 147 was performed to investigate the effect of dietary DHQ on the studied variables. Differences 148 were reported as significant at $\mathrm{P}<0.05$.

\section{RESULTS AND DISCUSSION}

151

152 All birds were healthy throughout the study period and there was no mortality. There was no 153 effect of treatment on any of the studied growth performance variables (Table 2).

154 The results on AMEn and nutrient retention coefficients are in accordance with previous 155 research (Pirgozliev et al. 2006, 2015; Whiting et al. 2016) and there were no differences $156(\mathrm{P}>0.05)$ between treatments (Table 3).

157 There were no differences $(\mathrm{P}>0.05)$ in the relative weights of the studied organs measured as 158 percentage of body weight (data not in tables) and the results were in agreement with previous 159 research (Dror et al.1977; Abdulla et al. 2016; 2017).

160 The results on chilling yield and the colour score were similar to these reported by Jeong et al. 161 (2011) (Table 4). The breast fillets of the birds fed DHQ had a higher red colour index (a*) 162 compared to the control fed birds $(\mathrm{P}<0.05)$.

163 The values for haemoglobin concentration and glutathione peroxidase were in agreement with 164 published reports (Tanaka and Rosenberg 1954; Elagib and Ahmed 2011; Popović et al. 2016) 
and there were no differences $(\mathrm{P}>0.05)$ between diets (Table 5). However, the results did not support the finding of Torshkov et al. (2014) for increased haemoglobin concentration in birds fed DHQ.

The values of hepatic vitamin E were in the expected range (Karadas et al. 2010, 2014; Whiting et al. 2018). However, no differences between dietary treatments were observed $(\mathrm{P}>0.05)$.

In the literature, dietary DHQ concentrations varied between studies and species. In poultry diets the concentration of supplemented DHQ varied from $1 \mathrm{mg}$ per kilogram live weight (Torshkov et al. 2014) to $40 \mathrm{mg}$ per $\mathrm{kg}$ live weight (Balev et al. 2015); in calves and cows, from 20 to $200 \mathrm{mg}$ per head daily (Fomichev et al. 2016); in weaning piglets from $10 \mathrm{mg}$ per $\mathrm{kg}$ feed (Fomichev et al. 2016), to $50 \mathrm{mg}$ per animal per day (Nikanova 2017). Research by Dunnick and Halley (1992) did not find any toxic effect of quercetin when fed to rats for 6 months at concentrations of up to $40000 \mathrm{ppm}$, and the estimated dose delivered was approximately 40-1900 mg/kg/day. Similarly, DHQ, which is closely related to quercetin in chemical structure, has been shown to be nontoxic when fed to albino rats and humans at much higher levels than in the reported study (Booth and DeEds 1958). There were no treatmentrelated effects on survival and no treatment-related clinical signs of toxicity for this period.

In the reported study, DHQ was added at $0.5 \mathrm{~g}$ per $\mathrm{kg}$ feed or $500 \mathrm{ppm}$. On average, birds were consuming approximately, $100 \mathrm{~g}$ feed per day, and their average daily weight gain was approximately $60 \mathrm{~g}$. Thus, the average daily consumption of DHQ was $0.05 \mathrm{~g}$ per bird, or 0.83 g per kilogram daily growth. The lack of adverse effects on birds health further confirms that DHQ is generally safe to use in broiler production. Further exploration of graded levels of dietary DHQ should be considered to optimise the dose required for enhanced production performance. 
188 In the reports by Fomichev et al. (2016) and Nikanova (2017), feeding DHQ generally improved the growth performance variables of animals reared in challenging conditions, i.e. high temperature. Fomichev et al. (2016) also reported that the response at later stage of 191 growing, i.e. $42 \mathrm{~d}$ old, was more pronounced compared to the early stage of growth ( $28 \mathrm{~d}$ age). 192 However, Balev et al. (2015) reared birds under industry-recognised conditions and did not 193 observe difference in growth performance of broilers fed DHQ for the entire period of 49 days. 194 Heat stress stimulates the release of corticosterone and catecholamines, increase the level of 195 free radicals and initiates lipid peroxidation in cell membranes (Freeman and Crapo 1982). 196 Prochazkova et al. (2011) suggested that flavonoids could prevent injury caused by free 197 radicals by the following mechanisms: direct scavenging of reactive oxygen species (ROS), 198 activation of antioxidant enzymes, metal chelating activity, reduction of a-tocopheryl radicals, 199 inhibition of oxidases, mitigation of oxidative stress caused by nitric oxide, increase in uric 200 acid levels, and increase in antioxidant properties of low molecular antioxidants. The mechanism of flavonoids health-promoting abilities is usually associated with their antioxidant properties (Andriantsitohaina et al. 2012) although recent findings suggest that flavonoids do not behave the same way in vitro and in vivo (Veskoukis et al. 2012). However, in the present study, birds were reared under standard industry recommended conditions, and no challenges were applied, possibly limiting the detection of the benefits of DHQ as an antioxidant.

206 In conclusion, supplementation of poultry diets with $0.5 \mathrm{~g}$ DHQ per $\mathrm{kg}$ feed, under standard industry rearing conditions, did not improve production performance or any of the studied health variables. However, the redness index of breast fillet was increased. Feeding DHQ at responses. 
214 Special thanks to Richard James and Rose Crocker for their technical support.

218 The authors reported no potential conflict of interest.

\section{REFERENCES}

Abdulla, J., Rose, S.P., Mackenzie, A.M., Mirza, M.W. and Pirgozliev, V. 2016. Exogenous tannase improves feeding value of diet containing field beans (Vicia faba) when fed to broilers. 224 British Poultry Science 57: 246-250.

Abdulla, J., Rose, S.P. and Mackenzie, A.M., and Pirgozliev, V. 2017. Feeding value of field beans (Vicia faba L. var. minor) with and without enzyme containing tannase, pectinase and xylanase activities for broilers. Archives of Animal Nutrition 71: 150 - 164. Andriantsitohaina, R., C. Auger, T. Chataigneau, N. Etienne-Selloum, H. Li, M.C. Martınez, 231 V.B. Schini-Kerth, and I. Laher. 2012. Molecular mechanisms of the cardiovascular protective 232 effects of polyphenols. British Journal of Nutrition 108: 1532-1549. 
234 AOAC. 2000. Official Methods of Analysis of the Association of Agricultural Chemists. 17

235 ed. Washington, DC: Association of Official Analytical Chemists.

236

237 Balev, D.K., A.S. Staykov, G.Y. Ivanov, S.G. Dragoev, and E.H. Filizov. 2011. Color stability

238 improvement of chilled beef by natural antioxidant treatment and modified atmosphere 239 packaging. American Journal of Food Technology 6(2): 117-28.

241 Balev, D., D. Vlahova-Vangelova, K. Mihalev, V. Shikov, S. Dragoev, and V. Nikolov. 2015. 242 Application of natural dietary antioxidants in broiler feeds. Journal of Mountain Agriculture 243 on the Balkans 18: 224-232.

245 Booth A.N., and F. DeEds. 1958. The toxicity and metabolism of dihydroquercetin. Journal of 246 the American Pharmaceutical Association (Scientific ed.) 47 (3): 183-184

Dragoev, S.G., A.S. Staykov, K.P. Vassilev, D.K. Balev, and D.B. Vlahova-Vangelova. 2014. Improvement of the quality and the shelf life of the high oxygen modified atmosphere packaged 250 veal by superficial spraying with dihydroquercetin solution. International Journal of Food 251 Science. http://dx.doi.org/10.1155/2014/629062

Dror, Y., I. Nir, and Z. Nitsan. 2007. The relative growth of internal organs in light and heavy 254 breeds. British Poultry Science 18 (4): 493-496, https://doi.org/10.1080/00071667708416389 
256 Dunnick J.K., and J.R. Halley. 1992. Toxicity and carcinogenicity studies of quercetin, a 257 natural component of foods. Toxicological Sciences 19: 423-431, 258 https://doi.org/10.1093/toxsci/19.3.423

Elagib, H.A.A., and A.D.A. Ahmed. 2011. Comparative study on haemoglobin values of blood

261 of indigenous chickens in Sudan. Asian Journal of Poultry Science 5:41-45

Fletcher, D. L., M. Qiao, and D. P. Smith. 2000. The relationship of raw broiler breast meat color and $\mathrm{pH}$ to cooked meat color and pH. Poultry Science 79: 784-788.

Fomichev, Y., L. Nikanova, and A. Lashin. 2016. The effectiveness of using dirydroquercetin 267 (taxifolin) in animal husbandry, poultry and apiculture for prevention of metabolic disorders, higher antioxidative capacity, better resistence and realisation of a productive potential of organism, Journal of International Scientific Publications, Agriculture \& Food 4: 140-159

Freeman B. A., and J. D. Crapo. 1982. Biology of disease: Free radicals and tissue injury. Laboratory Investigation 47: 412-426.

274 Hill, F. W., and D. L. Anderson. 1958. Comparison of metabolisable energy and productive 275 energy determinations with growing chicks. Journal of Nutrition 64: 587-603. 
277 Iskender, H., G. Yenice, E. Dokumacioglu, O. Kaynar, A. Hayirli, and A. Kaya. 2017.

278 Comparison of the effects of dietary supplementation of flavonoids on laying hen performance, 279 egg quality and egg nutrient profile. British Poultry Science 58: 550-556.

280

281

282

283

284

285

286

287

288

289

290

291

292

293

294 295

296

297

298

299

300
Ivanov, G., D. Balev, H. Nikolov, and S. Dragoev. 2009. Improvement of the chilled salmon sensory quality by pulverisation with natural dihydroquercetin solutions. Bulgarian Journal of Agricultural Science 2: 154-162.

Jeong, J.Y., K.K. Janardhanan, A.M. Booren, D.M. Karcher, and I. Kang. 2011. Moisture content, processing yield, and surface color of broiler carcasses chilled by water, air, or evaporative air. Poultry Science 90(3): 687-693.

Karadas, F., V. Pirgozliev, A. C. Pappas, T. Acamovic, and M. R. Bedford. 2010. Effects of different dietary phytase activities on the concentration of antioxidants in the liver of growing broilers. Journal of Animal Physiology and Animal Nutrition 94: 519-526.

Karadas, F., V. Pirgozliev, S. P. Rose, D. Dimitrov, O. Oduguwa, and D. Bravo. 2014. Dietary essential oils improve the hepatic anti-oxidative status of broiler chickens. British Poultry Science 55: 329-334. https://doi.org/10.1080/00071668.2014.891098

Nikanova, L.A. 2017 Application of antioxidants of dihydroquercetin in feeding of weaning piglets. The Russian Journal of Problems of Veterinary Sanitation, Hygiene and Ecology 3 (23): 78-82. 
Omarov, M.O., O.A. Clesareva, and C.O. Osmanova. 2016. Study of the effect of bioflavonoid-dihydroquercetin in the rations on protein concentration in the tissues and organs in broiler chickens. Collection of scientific works of the North Caucasian Research Institute of Animal Husbandry 2 (5). (УДК 636.52/.58.084/087)

Paglia, D.E., and W.N. Valentine. 1967. Studies on the quantitative and qualitative characterization of erythrocyte glutathione peroxidase. The Journal of Laboratory and Clinical Medicine 70: 158-169.

Pirgozliev, V.R., S.P. Rose, and P.S. Kettlewell. 2006. Effect of ambient storage of wheat samples on their nutritive value for chickens. British Poultry Science 47(3): 342-349.

Pirgozliev, V., M.W. Mirza, and S.P. Rose. 2015. Does the effect of pelleting depend on the wheat sample? Animal 10: 571-577.

Popović, S.J., L.J.M. Kostadinović, J.D. Lević, I.S. Čabarkapa, B.M. Kokić, and M.V. Vranješ. 2016. Assessment of a synbiotic effect on broiler productive performance and antioxidative enzymes activity. Journal of Animal and Plant Sciences 26(4): 887-892.

Prochazkova, D., I. Bousova, and N. Wilhelmova. 2011. Antioxidant and prooxidant properties of flavonoids. Fitoterapia 82: 513-523. 
323 Semenova, A.A., T.G. Kuznjecova, and V.V. Nasonova. 2008. Possibilities to application of

324 dihydroquercetin for stabilising quality of sausages produced from mechanically deboned 325 poultry meat. Tehnologija Mesa (Serbia), 49: 113-116. 326 http://scindeks.ceon.rs/article.aspx?artid=0494-98460804113S

327

328 Short, F.J., P. Gorton, J. Wiseman, J. and K.N. Boorman. 1996. Determination of titanium 329 dioxide added as an inert marker in chicken digestibility studies. Animal Feed Science and 330 Technology 59: 215-221.

331

Surai, P.F. 2014. Polyphenol compounds in the chicken/animal diet: from the past to the future. Journal of Animal Physiology and Animal Nutrition 98: 19-31.

Tanaka, T., and M. M. Rosenberg. 1954. Relationship between hemoglobin levels in chickens and certain characters of economic importance. Poultry Science 33 (4): 821-827, https://doi.org/10.3382/ps.0330821

Torshkov, A.A. 2011. Qualitative indicators of broiler meat using bioflavonoids. FGOU VPO 340 Orenburg State Agrarian University (УДК 637.043/.046)

341

342 Torshkov, A.A., A.N. Pershina, and T.V. Skvorcova. 2014. Hemoglobinization of erythrocytes of broiler chicken when using natural dietary supplements. Privolzskiy Naucnoy Vestnik (УДК 637.043/.046). 
346 Veskoukis, A.S., A. Kyparos, M.G. Nikolaidis, D. Stagos, N. Aligiannis, M. Halabalaki, K.

347 Chronis, N. Goutzourelas, L. Skaltsounis, and D. Kouretas. 2012. The antioxidant effects of a 348 polyphenolrich grape pomace extract in vitro do not correspond in vivo using exercise as an 349 oxidant stimulus. Oxidative Medicine and Cellular Longevity, 350 http://dx.doi.org/10.1155/2012/185867

351

352 Weidmann, A.E. 2012. Dihydroquercetin: more than just an impurity? European Journal of 353 Pharmacology 684: 19-26.

354

355 Whiting, I.M., V. Pirgozliev, S. P. Rose, J. Wilson, A.M. Amerah, S.G. Ivanova, G.P. 356 Staykova, O.O. Oluwatosin, and A.O. Oso. 2016. Nutrient availability of different batches of 357 wheat distillers dried grains with solubles with and without exogenous enzymes for broiler 358 chickens. Poultry Science 96: 574-580.

359

360 Whiting, I.M., V. Pirgozliev, S.P. Rose, F. Karadas, M.W. Mirza, and A. Sharpe. 2018. The 361 temperature of storage of a batch of wheat distillers dried grains with solubles samples on their 362 nutritive value for broilers. British Poultry Science 59:76-80 
Table 1. Ingredient composition of the control experimental diets (as fed).

\begin{tabular}{lcc}
\hline Ingredients $(\mathrm{g} / \mathrm{kg})$ & Grower & Finisher \\
\hline Barley & 79 & 67 \\
Wheat & 550 & 600 \\
Soybean meal & 230 & 190 \\
Full-fat soybeans & 50 & 50 \\
L Lysine HCL & 3 & 3 \\
DL Methionine & 3.5 & 3 \\
L Threonine & 1.5 & 1.5 \\
Soya oil & 45 & 47.5 \\
Limestone & 12.5 & 12.5 \\
Monocalcium phosphate & 12.5 & 12.5 \\
Salt & 2.5 & 2.5 \\
Sodium bicarbonate & 1.5 & 1.5 \\
Premix 1 & 4 & 4 \\
Titanium Dioxide & 5 & 5 \\
Calculated values $($ as fed) & & \\
Crude protein $(\mathrm{N} \mathrm{x} 6.25, \mathrm{~g} / \mathrm{kg})$ & 201 & 187 \\
Crude oil $(\mathrm{g} / \mathrm{kg})$ & 68 & 71 \\
ME $(\mathrm{MJ} / \mathrm{kg})$ & 12.99 & 13.17 \\
Calcium $(\mathrm{g} / \mathrm{kg})$ & 9.3 & 9.2 \\
Av Phosphorus $(\mathrm{g} / \mathrm{kg})$ & 4.2 & 4.2 \\
Av Lysine $(\mathrm{g} / \mathrm{kg})$ & 11.8 & 10.8 \\
Lysine $(\mathrm{g} / \mathrm{kg})$ & 12.7 & 11.6 \\
Methionine $+\mathrm{Cysteine}(\mathrm{g} / \mathrm{kg})$ & 9.4 & 8.4 \\
Tryptophan $(\mathrm{g} / \mathrm{kg})$ & 8.5 & 7.8 \\
Determined values & & \\
Dry matter $(\mathrm{g} / \mathrm{kg})$ & 894 & 893 \\
Gross energy $(\mathrm{MJ} / \mathrm{kg})$ & 17.43 & 17.39 \\
Crude protein $(\mathrm{N} \mathrm{x} 6.25, \mathrm{~g} / \mathrm{kg})$ & 194 & 181 \\
Crude oil $(\mathrm{g} / \mathrm{kg})$ & 69 & 66 \\
\hline
\end{tabular}

366

$367{ }^{1}$ The Vitamin and mineral premix contained vitamins and trace elements to meet the requirements specified by

368 NRC (1994). All the experimental diets were designed to be low in P. The premix provided (units $/ \mathrm{kg}$ diet): retinol

$3693600 \mu \mathrm{g}$, cholecalciferol $125 \mu \mathrm{g}, \alpha$-tocopherol $34 \mathrm{mg}$, menadione $3 \mathrm{mg}$, thiamine $2 \mathrm{mg}$, riboflavin $7 \mathrm{mg}$, pyridoxine

$3705 \mathrm{mg}$, cobalamin $15 \mu \mathrm{g}$, nicotinic acid $50 \mathrm{mg}$, pantotenic acid $15 \mathrm{mg}$, folic acid $1 \mathrm{mg}$, biotin $200 \mu \mathrm{g}$, iron $80 \mathrm{mg}$,

371 copper $10 \mathrm{mg}$, manganese $100 \mathrm{mg}$, cobalt $0.5 \mathrm{mg}$, zinc $80 \mathrm{mg}$, iodine $1 \mathrm{mg}$, selenium $0.2 \mathrm{mg}$ and molybdenium

$372 \quad 0.5 \mathrm{mg}$. 
374 Table 2. Production performance of broiler chickens fed control or dihydroquercetin (DHQ)

375 supplemented diets.

\begin{tabular}{lcccc}
\hline Item & Control & DHQ & SEM (DF=14) & P-value \\
\hline Feed Intake 7-35 d (g/b) & 2737 & 2788 & 29.5 & 0.268 \\
Weight Gain 7-35 d (g/b) & 1609 & 1666 & 36.0 & 0.300 \\
Feed Conversion Efficiency 7-35 d (g/g) & 0.588 & 0.599 & 0.0104 & 0.497 \\
Body Weight 35 d age $(\mathrm{g})$ & 1735 & 1790 & 29.9 & 0.232 \\
\hline
\end{tabular}


377 Table 3. Dietary apparent N-corrected metabolisable energy (AMEn) and nutrient retention 378 coefficients

\begin{tabular}{lcccc}
\hline Item & Control & DHQ & SEM (DF=14) & P-value \\
\hline AMEn (MJ/kg DM) & 13.60 & 13.52 & 0.0710 & 0.470 \\
Dry Matter Retention & 0.811 & 0.808 & 0.0062 & 0.574 \\
Nitrogen Retention & 0.738 & 0.737 & 0.0131 & 0.963 \\
Fat Retention & 0.844 & 0.835 & 0.0065 & 0.244 \\
\hline
\end{tabular}

379

380 Dietary AMEn and nutrient retention coefficients were determined between 32 and $35 \mathrm{~d}$ of age. 
Table 4. Chilling yield and surface colour of broiler breast fillets (within 5 minutes after slaughter) fed control or dihydroquercetin (DHQ) supplemented diets.

\begin{tabular}{lcccc}
\hline Item & Control & DHQ & SEM (DF=14) & P-value \\
\hline Chilling yield (\%) & 96.26 & 95.78 & 0.219 & 0.138 \\
L $^{*}$ & 49.1 & 52.1 & 2.83 & 0.484 \\
$\mathrm{a}^{*}$ & 2.24 & 3.42 & 0.170 & 0.002 \\
$\mathrm{~b}^{*}$ & 1.02 & 0.73 & 0.191 & 0.322 \\
\hline
\end{tabular}

384

385 
386 Table 5. Haemoglobin and glutathione peroxidase (GPx) in blood, and hepatic vitamin E of 387 broiler chickens fed control or dihydroquercetin (DHQ) supplemented diets.

\begin{tabular}{lcccc}
\hline Item & Control & DHQ & SEM (DF=14) & P-value \\
\hline Haemoglobin $(\mathrm{g} / \mathrm{l})$ & 132.1 & 133.6 & 3.07 & 0.735 \\
GPx $(\mathrm{u} / \mathrm{ml}$ RBC & 67.6 & 64.2 & 2.85 & 0.410 \\
Hepatic Vitamin E $(\mu \mathrm{g} / \mathrm{g})$ & 19.03 & 17.03 & 0.780 & 0.120 \\
\hline
\end{tabular}

388 